\title{
FEASIBILITY OF ENGINEERING PROJECTS. CASE IN THE COLOMBIAN PUBLIC SECTOR.
}

\section{VIABILIDAD DE PROYECTOS DE INGENIERÍA. CASO EN EL SECTOR PUBLICO COLOMBIANO}

\author{
MSc. Carlos David Peña Poveda*, PhD. Hugo Fernando Castro Silva* \\ PhD. Torcoroma Velásquez Pérez ${ }^{* *}$
}

* Universidad Pedagógica y Tecnológica de Colombia, Facultad Seccional Sogamoso. Calle 4 A Sur No. 15-134, Sogamoso, Boyacá, Colombia. Teléfono +57(8) 7723517. Fax (8) 7723518

E-mail: \{carlosdavid.pena, hugofernando.castro\}@uptc.edu.co. ** Universidad Francisco de Paula Santander Ocaña, Facultad de ingeniería. Sede el Algodonal Vía Acolsure, Ocaña, Norte de Santander, Colombia.

PBX: (+57) (7) 5690088.

E-mail: tvelasquezp@ufpso.edu.co.

\begin{abstract}
There is a high percentage of engineering projects in the public sector that are evaluated based on criteria based on time, cost and scope management, which are classified as failures. The objective of this research is to provide the results obtained in the observation of techniques and tools for managing the schedule, in engineering projects developed in the department of Boyacá - Colombia, during the period 2008 to 2018. Based on these results, a methodology is proposed to study the feasibility of this type of project. This methodology seeks the timely detection of deviations to the key success factors during the project life cycle in order to guarantee the achievement of the proposed objectives.
\end{abstract}

Keywords: Projects, project management, time management, project methodology.

Resumen: Existe un alto porcentaje de los proyectos de ingeniería del sector público que, evaluados a partir de los criterios basados en la gestión del tiempo, costo y alcance, que se clasifican como fracasos. El objetivo de esta investigación es proporcionar los resultados obtenidos en la observación de técnicas y herramientas de gestión del cronograma, en proyectos de ingeniería desarrollados en el departamento de Boyacá - Colombia, durante el periodo 2008 a 2018. Con base en estos resultados se propone una metodología para el estudio de la viabilidad de esta tipología de proyectos. Esta metodología busca la detección oportuna de desviaciones a los factores clave de éxito durante el ciclo de vida de los proyectos con el fin de garantizar el logro de los objetivos propuestos.

Palabras clave: Proyectos, gestión de proyectos, gestión de tiempo, metodología de proyectos

\section{INTRODUCTION}

Public infrastructure projects significantly impact society, they are developed through government plans and in principle develop the entities' mission and vision. Completing a project is of great importance to governments, as it becomes conclusive proof that public resources are being invested appropriately, achieving their objective, which is called project success.; on the other hand, the conditions of how they develop it is called success in project management, which is nothing more than a review from planning in the initiation processes, during execution and control, to the 
closure or completion of construction, This analysis concludes if the project has been a success or a failure.

The performance of the projects developed by the regional administration in the department of Boyacá, during the decade from 2008 to 2018, has shown that there is a phenomenon associated with the modification of the conditions originally planned, the foregoing serves as a basis for specifying that something has failed in the management of these works, this situation is reiterated in various studies worldwide; however, detecting the problem is not enough; In this work, a review is made and a methodological proposal is provided, focused on a corrective process, adapted to the shortcomings found, to improve the planning conditions and viability of the projects that are submitted for tender.

The public projects that are developed in the governments, have by nature to improve the quality of life of the people, its object is to satisfy an intrinsic or direct need of a population considered as a beneficiary or main stakeholder, engine by which the work is developed.

The way in which the infrastructure works are carried out, has led to characterize the management of public governments, creating a growing interest in improving the effects of planning in the part of the initiation processes and that directly influence the result of these. An observation over the years has shown that despite the interest in making public investments in this sector of the economy, the projects are not being conceived according to their planning, which indirectly questions whether there is a concept of sustainability in the development of the proposed objectives; not to go any further the concern is inherent in that the department of Boyacá will enjoy a significant investment, which according to the DNP (national planning department) and the national development plan in the department will be invested about 22.1 billion pesos in the coming years, and that would benefit 1.3 million people (DNP, 2019)

On the other hand, it is usual that, in more than one public administration for the period conceived, infrastructure works that had to be completed in the administrations where they were raised end up being resolved. Even though the literature has sequentially addressed the revision of the causes of late terminations and cost overruns and road constructions, it has not delved into the factors of own origin of governments (Catalão, Cruz, \&
Sarmento, 2019), It is important that selfevaluation is generated from the public administration itself and that it is possible to determine if it is the viability granted to each of the projects, an aspect that influences the planned final result; likewise, the execution time of these works becomes subjective, since naturally, the conditions under which they are designed do not satisfy the initial parameters, revealing that there is a waste of resources, causing the results to be wasted and, in turn, that there is disapproval on the part of the interested parties, as a result of the fact that the expectation designed in time, cost and quality for the projects in that resources are invested.

Then the Hypothesis or research question is: Why do the public infrastructure projects issued by the Boyacá Governorate not finish as planned in time, after viability has been generated, and the obtained result is observed as a failure in their management?

Projects, like governments, are temporary efforts, with very well defined periods; in Colombia, according to article 303 of the political constitution, the term is four years of Government for the positions of Governor of the department, without the right to reelection (Political Constitution of Colombia, 1991)

Our country has a great diversity of cultures and political parties, which increases the possibility that different governments are not related to infrastructure works planned in previous governments, which may cause obstacles and/or limitations to those that are currently developing. Given this condition, for the administrations, it is necessary that each one of the projects destined for the benefit of the citizens, significantly improve the effects of planning and, in turn, have fewer incidents and unforeseen events than those usually observed.

Achieving appropriate management factors and indicators in the viability of the projects will not only allow real planning to be carried out but will also be reflected in the development and materialization of the works, considering that they are factors that naturally have affected not only the development of road constructions and buildings in Colombia but in other countries, as shown in the figure 1. 


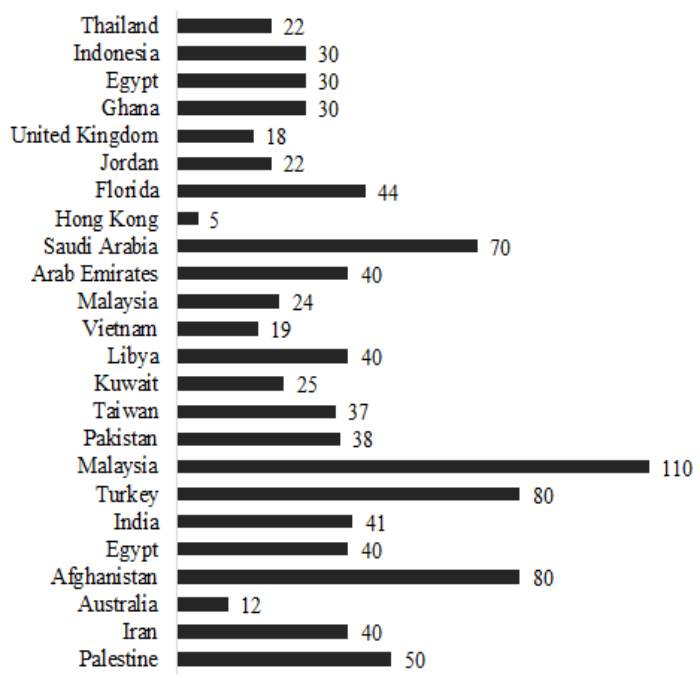

Fig. 1 Classification of the number of cases collected from the literature review, own source, adaptation to based on Aziz \& Abdel-Hakam, (2016)

According to the PMI, a project is "a temporary effort that is carried out to create a unique product, service or result". (PMI, 2017, p.4). When introducing the term of projects indirectly, their management must be involved, which includes the areas of planning, monitoring, organization, and control focused on the materialization of the objective (Radujković \& Sjekavica, 2017).

Achieving the success of the projects is part of an empirical equation in which the cost, scope and time are evaluated, however, their characterization is limited to different perceptions (Sanchez, Terlizzi, \& de Moraes, 2017). Successful completion of projects shows that the results of a work team are visible and can be identified as achievements achieved or successful. The success in the projects is identified with the fulfillment of expectations of a certain interested party (Alias, Zawawi, Yusof, \& Aris, 2014). According to the assessment made by (Cooke-Davies, 2002), success can be differentiated into two stages, one related to the achievement of the objectives which is called project success and another called project management success and which makes part of the evaluation of the iron triangle measuring factors such as cost, scope, and quality. Important contributions directly related to project management punctually measure functional criteria in which project scheduling, budgets and performance are found, with a particular sense to determine project performance (Radujković \& Sjekavica, 2017).
It is natural to observe that from the perspective of project management and their success, what Radujkovic and others mention can be indicated, evidence that the results of a project can be diverse, that is, they can be successfully concluded when the achievement of the material objectives, however, the project management would take a turn when these objectives were not achieved and would be seen as unsuccessful (Radujković \& Sjekavica, 2017).

The success of the project is influenced by different factors. Research in Colombian projects has shown that the style of managing conflict within the project team influences the achievement of the project's objectives (Diez-Silva, MontesGuerra \& Castro-Silva, 2020; Castro-Silva, Rodríguez Cañas, Montes -Guerra, 2020). Also, in Colombia, investigations into projects in the construction sector have shown that the project's success is influenced by dimensions of sustainable development such as the social, environmental and economic dimensions (Castro-Silva, RinconGonzález \& Diez-Silva, 2020).

In projects and processes, it is important to consider that in order to respond in a timely and effective way to changes in the environment, the technological incorporation of service-oriented services is necessary (Mendoza, Escobar \& Caicedo, 2019; Rosado \& Jaimes, 2017). In this same area of information technology projects, it is argued that a good architecture for information management tends to the success of the project (Castro Márquez, Velásquez, Castro-Silva, 2018; Martínez \& Carrillo, 2017). Likewise, in information technology projects it is important to define and implement a governance model based on international standards such as COBIT and ISO (Velásquez, Pérez \& Flórez, 2018).

By structuring infrastructure projects that are resolved in public administrations, it has been shown that the results can be successful in the objective, but failed in its management, which when understood in a comprehensive evaluation would conclude with variable results to those initially proposed; So much so that the three main reasons for project failure are directly related to changes in the organization's priorities, changes in project objectives and requirements compilation errors (PMI, 2018) becoming the fundamental factors that compromise the scope, cost, and duration of the project. According to the performance of projects in the infrastructure sector, guaranteeing the success of project management 
depends significantly on how it has been managed and controlled, with the factors of the iron triangle added to the effects of planning and developing it, that most impacts the results. (Alias, Zawawi, Yusof \& Aris, 2014).

One of the best ways to track projects is through indicators; the data obtained is useful to determine the performance of the projects and that they are constantly evaluated towards the fulfillment of the objectives and thus observe the failures that arise in their execution and that may limit the final result of the project (S, Vyas Gayatri S, 2013).

The viability in public infrastructure projects plays a special role in the development and execution of works, starting from a strategic base in which costs, time and scope intervene; Literature reviews have indicated that project cost overruns have become globally widespread and that they are affected from the initiation processes (Love, Ahiaga-Dagbui, \& Irani, 2016). According to what was mentioned by (Li, Ng, \& Skitmore, 2013), it is important to address aspects prior to the execution of the projects, such as knowing the expectations and concerns of the population and that can affect the result of the project leading to failure. , a study that consisted of creating a model to evaluate public participation through the satisfaction of stakeholders.

To be more precise, one of the influencing factors in the projects has been described by (Lee, Won, Jang, Jung, Han \& Kwat, 2017) who analyzed the effects of the management of social conflicts for the viability of public projects, in The study carried out proposed a conflict management model applied to 22 public projects, identifying 5 possibilities of conflict results that are early project termination, early mitigation, late mitigation, project execution, and late occurrence. Another approach towards influencing stakeholder conflict and social conflict in projects have been observed by (Liu, Zhu, Wang, \& Huang, 2016) and (Jia, Yang, Wang, Hong, \& You, 2011), according to These studies have identified that there are close relationships in the origin of megaprojects and economic development as a result of social conflict and that by linking work teams for risk management, it reduces the uncertainty of project implementation.

As indicated by Leonardo Sierra and others, the evaluation of the viability of the projects includes aspects from different fields in which the economy, environment, technical conditions and social aspects are involved (Sierra, Yepes and Pellicer,
2017). Another crucially important aspect is communication, an investigation on the development of infrastructure projects indicates that it is necessary to maintain communication during the life cycle of the project, a study carried out in Finland, where they explored what environmental and social aspects influence the development of infrastructure projects from their planning (Landauer \& Komendantova, 2018)

Environmental aspects have shown to have a direct influence on the results of the projects, a study proposed optimizing a methodology in which they proposed an integrating model in which climatic conditions are considered; In the research it is emphasized that how projects are developed has a significant impact on how they are developed, impacting on cost and completion date, the climate is the object of analysis. (Kerkhove \& Vanhoucke, 2017)

One of the sectors most sensitive to change is seen in the public sector; In the development of works contracts, it is common for cost overruns and delays to be a regular part of projects, especially in the execution stage, taking into account the possibility of repercussions on the finances and sustainability of the main stakeholders (Adam, Josephson, \& Lindahl, 2015) and (Cavalieri, Cristaudo, \& Guccio, 2019), A study that analyzed 42 influencing factors in the cost of projects, concluded that of these, 16 are the ones that most impacts represent in the increase of costs, in which is the scope of the project, cost control and conflict of the contract without forget the environmental influence (Cheng, 2014). Cost overruns and time exceeded in works are topics studied in Qatar, Afghanistan, and Jordan, concluding that factors such as climate, owners, change in scope and time out of the base, financial difficulties, changes in regulations and laws proved to be the most influential, (Senouci, Ismail, \& Eldin, 2016),(Niazi \& Painting, 2017), (Al-Hazim, Salem, \& Ahmad, 2017) and (Khlaifat, Alyagoub, Sweis, \& Sweis, 2019)

In the study by Rachid et al., Factors influencing project delays in Algeria were identified; the research compiled the information of 16 owners, 20 consultants, and 16 contractors, resulting in an unrealistic duration, planning, late payments and unrealistic schedules are the aspects that most influence the delay of projects (Rachid, Toufik, \& Mohammed, 2018), statement shared in the same sense by other authors (Arantes, Da Silva, \& Ferreira, 2016), (Odeh \& Battaineh, 2001) and 
(Tafazzoli \& Shrestha, 2017), adding that there are direct effects due to changes in the scope, type of tender and method of award, asserting that the presence of these topics often ends with financial variation and execution time.

According to the research carried out by Aziz and Abdel, who studied the effects of delays in projects in Egypt, they obtained results that show that there are factors that also influence, such as the work team, design, factors specific to the contractor, typical of the contract. , quality and availability of materials, consulting, programming and property owners.(Aziz \& Abdel-Hakam, 2016). Similar studies carried out in India and Malaysia, are not unrelated to these investigations, they have shown that factors of a social, economic and planning type, can harm the results of the development of works. (Doloi, Sawhney, Iyer, \& Rentala, 2012), y (Sambasivan \& Soon, 2007).

Other studies carried out in India and Saudi Arabia have determined that business finances and payments are one of the essential elements for delaying projects (Prasad, Vasugi, Venkatesan, \& Bhat, 2019) and (Abdellatif \& Alshibani, 2019). In an analysis of 72 projects in Iran, the existing relationship in the cost of the projects and their duration was evaluated. Within this work, they considered that the type of project, planning, and expected duration are those that are most related to the Projects. (Heravi \& Mohammadian, 2019). 20 infrastructure projects evaluated in Norway, suggest that best practices in the initiation processes influence the positive result of the projects, however, there is a need to not only evaluate projects at the beginning but at the end, since it can improve the results for future investments.(Volden, 2018).

\section{METHODOLOGY}

The methodology used is of the applied type, with a formal deductive process in which the phenomena that intervene in the management of projects in the planning stage can be observed to grant the viability of these. A quantitative approach is used by being able to make statistics associated with time management and the performance index of the schedule of public infrastructure projects, made viable in the department of Boyacá in a particular period.

The research carried out in this work shows the results obtained in observing the time management of a decade of construction of public infrastructure projects, carried out in the department of Boyacá, from 2008 to 2018, is presented in three different phases with which the problem is validated and ends with the contribution of a methodological adaptation suggestion.

Characterization of the contracting processes published on the website of the electronic public contracting system which is governed by article 3 of law 1150 of 2007(Ley 1150, 2007).

\section{Table 1 Parameters for search equations on the SECOP website and results}

\begin{tabular}{|c|c|c|c|}
\hline Parameters & Equation 1 & Equation 2 & Equation 3 \\
\hline $\begin{array}{l}\text { Buying } \\
\text { Entity } \\
\text { Product or } \\
\text { Service }\end{array}$ & $\begin{array}{c}\text { Boyacá - } \\
\text { government } \\
\text { F- Building } \\
\text { services, } \\
\text { facilities } \\
\text { construction and } \\
\text { maintenance. }\end{array}$ & $\begin{array}{c}\text { Boyacá - } \\
\text { government } \\
\text { F- Building } \\
\text { services, } \\
\text { facilities } \\
\text { construction and } \\
\text { maintenance. }\end{array}$ & $\begin{array}{l}\text { Boyacá - } \\
\text { government } \\
\text { G- Land, } \\
\text { buildings, } \\
\text { structures and } \\
\text { roads. }\end{array}$ \\
\hline $\begin{array}{l}\text { Modality of } \\
\text { contracting } \\
\text { Execution }\end{array}$ & $\begin{array}{l}\text { Public Works } \\
\text { Tender }\end{array}$ & Public tender & Public tender \\
\hline $\begin{array}{l}\text { Department } \\
\text { Date from }\end{array}$ & $01 / 01 / 2008$ & $01 / 01 / 2008$ & $01 / 01 / 2008$ \\
\hline Amount & $\begin{array}{l}\text { Greater than } \$ \\
1.000 .000 .000\end{array}$ & $\begin{array}{l}\text { Over } \\
1,000,000,000\end{array}$ & $\begin{array}{l}\text { Over } \\
1,000,000,000\end{array}$ \\
\hline $\begin{array}{l}\text { Process } \\
\text { number }\end{array}$ & ------------------ & ------------------ & ----------------- \\
\hline State & $\begin{array}{c}\text { All process } \\
\text { states }\end{array}$ & $\begin{array}{c}\text { All process } \\
\text { states }\end{array}$ & $\begin{array}{c}\text { All process } \\
\text { states }\end{array}$ \\
\hline Municipality & $\begin{array}{c}\text { All } \\
\text { municipalities }\end{array}$ & $\begin{array}{c}\text { All } \\
\text { municipalities }\end{array}$ & $\begin{array}{c}\text { All } \\
\text { municipalities }\end{array}$ \\
\hline $\begin{array}{l}\text { Date Until } \\
\text { Results per } \\
\text { page }\end{array}$ & $\begin{array}{c}12 / 31 / 2018 \\
100\end{array}$ & $\begin{array}{c}12 / 31 / 2018 \\
100\end{array}$ & $\begin{array}{c}12 / 31 / 2018 \\
100\end{array}$ \\
\hline $\begin{array}{l}\text { Records } \\
\text { found }\end{array}$ & $\begin{array}{c}\text { Equation } 1 \\
7\end{array}$ & $\begin{array}{c}\text { Equation } 2 \\
83\end{array}$ & $\begin{array}{c}\text { Equation } 3 \\
38\end{array}$ \\
\hline $\begin{array}{c}\text { TOTAL } \\
\text { Web page } \\
\text { consulted }\end{array}$ & \multicolumn{3}{|c|}{ https://www.contratos.gov.co/consultas/inicioConsulta.do } \\
\hline
\end{tabular}

\section{RESULTS}

From the search equations proposed, a total of 128 records equivalent to $100 \%$ of the sample were obtained, characterized in Table 2 and distributed in Figure 1.

\section{Table 2: Characterization of the sample obtained with the applied equations}

\begin{tabular}{ccl}
\hline Id & Percentage & \multicolumn{1}{c}{ Component characterization } \\
\hline A & $57,8 \%$ & $\begin{array}{l}\text { Registers evaluated: All the processes of } \\
\text { the search equations that, due to the } \\
\text { information available in the (SECOP), } \\
\text { allowed for an evaluation. } \\
\text { Records not evaluated: All the processes } \\
\text { of the search equations that, due to the } \\
\text { absence of information available in the } \\
\text { (SECOP), an evaluation was not allowed. }\end{array}$ \\
& &
\end{tabular}




\begin{tabular}{|c|c|c|}
\hline C & $3,1 \%$ & $\begin{array}{l}\text { Atypical records: All the processes of the } \\
\text { search equations that, based on information } \\
\text { available in the (SECOP), were interpreted } \\
\text { as excluding and particular cases than } \\
\text { those presented in group A. }\end{array}$ \\
\hline D & $25,0 \%$ & $\begin{array}{l}\text { Invalid records: All the processes of the } \\
\text { search equations that, based on information } \\
\text { available in the (SECOP), were interpreted } \\
\text { as bidding processes not carried out by the } \\
\text { contracting entity, therefore, they are } \\
\text { equivalent to deserted records and / or } \\
\text { revoked. }\end{array}$ \\
\hline $\mathbf{E}$ & $5,5 \%$ & $\begin{array}{l}\text { Records in progress: All the processes of } \\
\text { the search equations that, based on } \\
\text { information available in the (SECOP), } \\
\text { were interpreted as projects in progress, } \\
\text { not completed and without modifications } \\
\text { and / or extensions that show an } \\
\text { approximate behavior such as that } \\
\text { presented in the group A, that is, they are } \\
\text { not taken into account for evaluation } \\
\text { because as of July 10, 2019, it was chosen } \\
\text { to identify them as successful and } \\
\text { unsuccessful, until their completion, can } \\
\text { carry them out, and classify them as } \\
\text { adequate processes for observation. } \\
\text { TOTAL SAMPLE }\end{array}$ \\
\hline
\end{tabular}



Fig. 2: Distribution of results of the applied equations

From sample A represented by $57.8 \%$ of the records of the applied search equations, they were taken to a quantitative analysis stage that consisted of evaluating the time behavior of this set. To adequately present this result, the information obtained was classified into 8 groups. It was awarded to the item of successful management, for those projects that in its management were in the range of $<=-1<=0,0999$, being equivalent to $100 \%$ of lower limit management and $9.999 \%$ additional in an upper time limit; the technique used to determine the tolerance limit corresponds to an empirical measurement of the static type, which by what Vanhoucke indicated, in projects arbitrary value thresholds can be established that must not be exceeded (Vanhoucke, 2019); Table 3 and Figure 2 show the classification used for this work. The data presented serves to identify and qualify the success or failure of project management, for this reason, no additional results will be presented for phase I.

\section{Table 3: Characterization parameters of sample A}

\begin{tabular}{lcl}
\hline Group result & $\begin{array}{c}\text { Parameter } \\
\text { Evaluation }\end{array}$ & \multicolumn{1}{c}{ Qualification } \\
\hline R Group 1 & $<=-1<=0,0999$ & Successful Management \\
R Group 2 & $>=0,1<=0,99$ & Failed management \\
R Group 3 & $>=1,0<=1,99$ & Failed management \\
R Group 4 & $>=2,0<=2,99$ & Failed management \\
R Group 5 & $>=3,0<=3,99$ & Failed management \\
R Group 6 & $>=4,0<=4,99$ & Failed management \\
R Group 7 & $>=5,0<=6,99$ & Failed management \\
R Group 8 & $>=7,0$ & Failed management \\
\hline
\end{tabular}

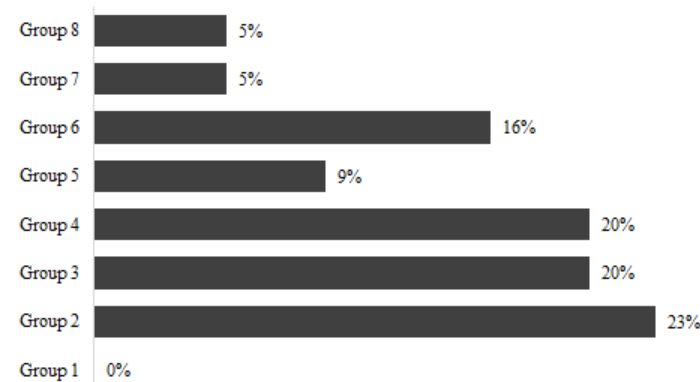

Fig. 3 Distribution of results by evaluation groups

Table 4 compiles the behavior according to the evaluation parameters chosen for the development of this work, clarifying that the 74 public infrastructure projects in sample A (or $57.8 \%$ of the 128 records of the equations) were reviewed search.

\section{Table 4: Average results by association group}

\begin{tabular}{lclcc}
\hline Group 1 & 0 & $\begin{array}{l}<=-1 \\
<=0,0999\end{array}$ & 0 & $0 \%$ \\
Group 2 & 17 & $>=0,1<=0,99$ & 0,51 & $51 \%$ \\
Group 3 & 15 & $>=1,0<=1,99$ & 1,41 & $141 \%$ \\
Group 4 & 15 & $>=2,0<=2,99$ & 2,39 & $239 \%$ \\
Group 5 & 7 & $>=3,0<=3,99$ & 3,45 & $345 \%$ \\
Group 6 & 12 & $>=4,0<=4,99$ & 4,52 & $452 \%$ \\
Group 7 & 4 & $>=5,0<=6,99$ & 6,14 & $614 \%$ \\
Group 8 & 4 & $>=7,0$ & 23,34 & $2334 \%$ \\
TOTAL & 74 & & & \\
\hline
\end{tabular}

For the characterization of the 128 records, a particular observation was made on each one, any document that, by its nature, quantitatively identified the duration time of each of the processes developed by the Boyacá Government in the period comprised by $01 / 01 / 2008$ to $12 / 31 / 2018$.

Clarifying the above, a review was made of the documents mentioned in Table 5, no qualification 
restriction was applied due to the absence of one or more documents; in specific cases, it was decided to carry out time calculations, made from the presence of 1 or more dates and the current initial and / or final duration of the project - table 6, which facilitated the full set of requirements to be considered part of the group Analysis A.

\section{Table 5: Documents made available for evaluation}

\begin{tabular}{|c|c|c|}
\hline Act of liquidation & & When warranted \\
\hline $\begin{array}{l}\text { Final receipt certificate } \\
\text { satisfaction }\end{array}$ & to & When warranted \\
\hline Act of termination & & When warranted \\
\hline Partial record & & When warranted \\
\hline Contract & & When warranted \\
\hline Modifications & & When warranted \\
\hline Additional in time and/or value & & When warranted \\
\hline Suspension records & & When warranted \\
\hline Restart minutes & & When warranted \\
\hline Policies & & When warranted \\
\hline
\end{tabular}

Table 6: How to obtain results

\begin{tabular}{lc}
\hline \multicolumn{1}{c}{ Data type } & Result \\
\hline Initiation date & Date 1 \\
Finish date & Date 2 \\
Real termination date & Date 3 \\
$\begin{array}{l}\text { Ideal project performance } \\
\text { (days) }\end{array}$ & Result $1=$ Date 2-Date \\
$\begin{array}{lc}\text { Real project performance } \\
\text { (days) }\end{array}$ & 1 \\
$\begin{array}{l}\text { Additional days (days) for the } \\
\text { project }\end{array}$ & Result $2=$ Date $3-$ Date \\
\% Of additional time & 1 \\
& Result 3 $=$ result 2- \\
& result 1 \\
\hline
\end{tabular}

Phase II: Characterization of the origin of the arguments of suspensions and additional in time of sample A of phase I, the information was obtained from the official documents published as of July 10,2018 , from each of the 74 records used as valid samples in the search equations presented above.

From the review carried out in phase I of this work, it was decided to qualitatively analyze the justifications used in the 74 records, to carry it out, a review of the following documents was generated: Acts of suspension, extensions, and additional in time, a total of 312 results were obtained, which were used to modify the conditions initially proposed in the projects. They were classified into 8 association groups, according to the arguments that were the reasons that justified the time shift. The results can be seen in Table 7 and Figure 4.

\section{$\underline{\text { Table } 7 \text { Association group factors }}$}

Group $\quad$ Type factor $\quad$ Observation

\begin{tabular}{|c|c|c|}
\hline $\begin{array}{l}\text { Group } \\
\text { A } 1\end{array}$ & $\begin{array}{l}\text { Environmental } \\
\text { and/or climatic }\end{array}$ & $\begin{array}{l}\text { Torrential rains, droughts, } \\
\text { earthquakes, fires, floods, among } \\
\text { others. }\end{array}$ \\
\hline $\begin{array}{l}\text { Group } \\
\text { A } 2\end{array}$ & Social & $\begin{array}{l}\text { Unemployment, marches, sit-ins, } \\
\text { property management, private } \\
\text { requests from citizens, among } \\
\text { others. }\end{array}$ \\
\hline $\begin{array}{l}\text { Group } \\
\text { A } 3\end{array}$ & $\begin{array}{l}\text { Studies and } \\
\text { designs }\end{array}$ & $\begin{array}{l}\text { Absence of studies and designs, } \\
\text { poorly prepared studies, } \\
\text { additional requirements not } \\
\text { considered, among others. }\end{array}$ \\
\hline $\begin{array}{l}\text { Group } \\
\text { A } 4\end{array}$ & $\begin{array}{l}\text { Festivities } \\
\text { (end of the } \\
\text { year / Easter) }\end{array}$ & $\begin{array}{l}\text { Special dates characteristic of the } \\
\text { population, which limits the } \\
\text { execution of the work due to the } \\
\text { cessation of activities of all kinds. }\end{array}$ \\
\hline $\begin{array}{l}\text { Group } \\
\text { A } 5\end{array}$ & $\begin{array}{l}\text { Permits, } \\
\text { licenses, } \\
\text { procedures }\end{array}$ & $\begin{array}{l}\text { Absence of any preliminary } \\
\text { document, previous step or } \\
\text { essential requirement among } \\
\text { others }\end{array}$ \\
\hline $\begin{array}{l}\text { Group } \\
\text { A } 6\end{array}$ & $\begin{array}{l}\text { Technical } \\
\text { Origin }\end{array}$ & $\begin{array}{l}\text { Construction specifications, } \\
\text { construction procedures, greater } \\
\text { amounts of work, unanticipated } \\
\text { activities, closed roads, among } \\
\text { others. }\end{array}$ \\
\hline $\begin{array}{l}\text { Group } \\
\text { A } 7\end{array}$ & $\begin{array}{l}\text { Changes in the } \\
\text { scope of the } \\
\text { project }\end{array}$ & $\begin{array}{l}\text { Variations of requirements in the } \\
\text { execution of projects, the } \\
\text { introduction of new requirements } \\
\text { not contemplated in the initial } \\
\text { stage, among others. }\end{array}$ \\
\hline $\begin{array}{l}\text { Group } \\
\text { A } 8\end{array}$ & Economic & $\begin{array}{l}\text { Lack of resources to materialize } \\
\text { the scope, economic factors for } \\
\text { the main stakeholders of the } \\
\text { project, among others. }\end{array}$ \\
\hline
\end{tabular}

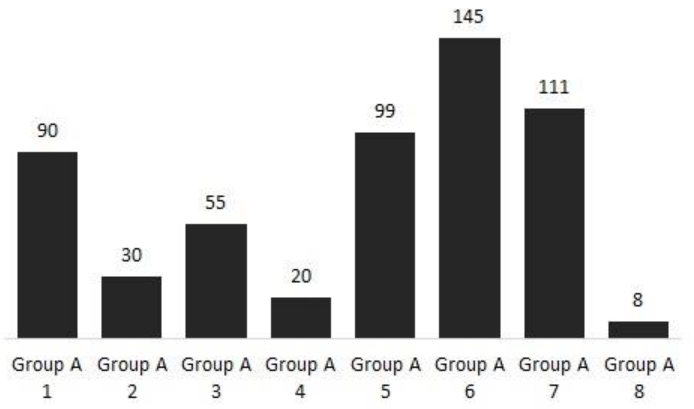

Fig. 4 Behavior of factors that require additional time.

Following the concepts presented and cited by the council of state (State Council Chamber, 2016), which indicates that a suspension is due to a mutually agreed decision, which affects the execution period to achieve compliance, and that in the case of an additional in time or extension refers to a modification to the initial agreement; It is relevant to accept these terms since they demonstrate the behavior in the development of the evaluated projects. For all cases, they are considered to be factors that apply due to their impact on the normal development of a work.

Phase III: Methodological review: The Boyacá Governorate has in its viability process a series of aspects and requirements that influence the 
initiation stage of the project, for this purpose, make use of the manual procedures document of the program and project bank / PE-M-01 (Boyacá Governorate, 2014) E-DE-FP-M-001 (Boyacá Governorate, 2019); Considering that in this content verification of aspects of requirements for viability was carried out, and according to the results obtained in Phase II, a proposal is made based on the use of the parameters used by the State of New York and the PMI., which will function as alternative measures to promote success in project management success.

\section{Table 2: Viability parameters - Proposal for modification.}

\begin{tabular}{lcl}
\hline \multicolumn{1}{c}{$\begin{array}{c}\text { Methodological } \\
\text { proposal }\end{array}$} & $\begin{array}{c}\text { GB } \\
\text { Methodology }\end{array}$ & Change action \\
\hline $\begin{array}{l}\text { Methodological } \\
\text { feasibility } \\
\text { Feasibility studies and } \\
\text { designs }\end{array}$ & $\checkmark$ & $\begin{array}{l}\text { Maintain } \\
\text { criteria } \\
\text { Environmental } \\
\text { feasibility and other } \\
\text { permits, licenses, }\end{array}$ \\
$\begin{array}{l}\text { procedures } \\
\text { Institutional / legal } \\
\text { feasibility } \\
\text { Socio-economic } \\
\text { viability }\end{array}$ & $\boldsymbol{x}$ & $\begin{array}{l}\text { Mdd criteria } \\
\text { criteria }\end{array}$ \\
\hline Technical viability & $\checkmark$ & $\begin{array}{l}\text { Maintain } \\
\text { criteria } \\
\text { Modify } \\
\text { criteria }\end{array}$ \\
Damping time & $\checkmark$ & $\begin{array}{l}\text { Maintain } \\
\text { criteria } \\
\text { Add criteria }\end{array}$ \\
\hline
\end{tabular}

* Methodological proposal: Suggested methodology in this work (Climbing feasibility and damping time) / * GB Methodology: Current criteria used by the Boyacá Government /* Change action: Quality in which the modification is suggested $/ *$ Structure: Justification and model of change.

The structure of each of the criteria of the methodological proposal shown in Table 9 is described below:

- Methodological feasibility: The criteria provided in the procedures and projects bank procedures manual / PE-M-01 (Gobernación de Boyacá, 2014) - E-DE-FP-M-001 (Gobernación de Boyacá, 2019), must be maintained to grant the viability of the project.

- Feasibility studies and designs: It is suggested to add the criteria presented under the following structure.The project meets the requirements for phase III studies and designs, necessary for the development of the project. Rating: YES / NO.

The designs provided comply technically and documentaries with the signatures of the respective specialists, responsibility reports, digital copy in the format of the respective software, and scanner of the original documents. Rating: YES / NO

- Environmental feasibility and other permits, licenses, procedures: It is suggested to modify the name of the current item by Environmental feasibility and other permits, licenses or procedures, as well as to transform the criteria by the following item of calcification The permits required for the project are duly issued and approved, and are in effect at the time of project viability. Rating: YES / NO.

- Institutional / legal feasibility: The criteria provided in the procedures and projects bank procedures manual / PE-M-01 (Gobernación de Boyacá, 2014) - E-DE-FP-M-001 (Gobernación de Boyacá, 2019), must be maintained to grant the viability of the project.

- Socio-economic viability: It is suggested to modify the criteria, adding the following topic to the current structure: Stakeholder analysis was performed, expectations, uncertainties, concerns and / or any factor associated with the project were known. Rating: YES / NO.

Those interested have knowledge of the project, were duly informed, at the initiation stage, and were granted a favorable concept to proceed with the start of the project. Rating: YES / NO.

- Technical viability: The criteria provided in the procedures and projects bank procedures manual / PE-M-01 (Gobernación de Boyacá, 2014) - E-DE-FP-M-001 (Gobernación de Boyacá, 2019), must be maintained to grant the viability of the project.

- Damping time: It is suggested to add the criteria presented under the following structure: Due to its geographical location, the project requires additional compensatory time in execution, due to weather conditions, festivities or technical factors that may influence the normal development of the works. Rating: YES / NO APPLIES

In this document, a methodological proposal has been presented that projects two types of alternatives: in the first case, a term adapted to the damping time (solution to factors that prevail in the possibility of generating displacement in the timeline available for achieving the scope of the project) and in the second case, the viability of escalation (solution to factors that affect the development of time from the beginning). 
For the first, the methodology incorporates perception aspects and criteria, that is, the viabilizer will autonomously define the need or not to involve these factors in the development of the projects. In this event, the groups of phase II are included: A1, A4 and A6. These represent aspects not unknown, but neither are they mandatory. In the second case is the viability of escalation, which, unlike the first, are controllable factors from the origin, because when modifying them in the viability, this will be reflected in the final result beginning; It is made up of phase II groups A2, A3, A5 and A7. These aspects have been considered because they affect the critical path of any project. Group A8 is part of the feasibility of the project.

\section{CONCLUSIONS}

The success of the project management is the result of the rigor with which the initial structure of the project is made, therefore, the evaluation generated in the time scale and the three equations defined in this work in phase I - Characterization of processes contracting, has been classified as failures in its management, the result of not applying adequate methodologies or good project management practices, which may lead to the presence of negative aspects that directly affect the interested population, the economic interests of construction companies, the stagnation of regional and local development, with an aggravating circumstance leading to a perception of corruption.

The object of study of this research, the developed projects have been exposed to receive viability without the requirement or fulfillment of essential requirements, such as those that have been evidenced in phase II - characterization of delays, being the most relevant those of the group ( permits, licenses, and procedures), A6 (technicians) and A7 (changes in the scope of the project), the reasons that have led to the determination that these works have been considered to have failed in their management, information reflected in phase 1 , which shows the displacement of time ; which indirectly corroborates that there was low inclusion of good management practices during these 10 years of project execution..

On the other hand, in the case of the process manual used by the Boyacá Governorate, observed from the perspective of project administration and management, it is consistent that what was identified in phase II - Characterization of arguments, is interpreted as a significant affectation in the success of project management, despite the fact that the departmental administration includes various aspects of requirements in its feasibility argument, as shown in Table 9 "GB methodology", it has become evident that there are flaws in the development of the same that have demanded the need for some suspension and / or extend; therefore, although it is true, these are proper requirements, they must be adjusted to actual qualification measures such as those proposed in this document in section 7.3.1 of phase III methodological review.

\section{REFERENCES}

Abdellatif, H., \& Alshibani, A. (2019). Major Factors Causing Delay in the Delivery of Manufacturing and Building Projects in Saudi Arabia. Buildings, 9(4), 93. https://doi.org/10.3390/buildings9040093

Adam, A., Josephson, P.-E., \& Lindahl, G. (2015). Implications of Cost Overruns and Time Delays on Major Public Construction Projects. Proceedings of the 19th International Symposium on Advancement of Construction Management and Real Estate, 747-758. https://doi.org/10.1007/978-3-66246994-1_61

Al-Hazim, N., Salem, Z. A., \& Ahmad, H. (2017). Delay and Cost Overrun in Infrastructure Projects in Jordan. Procedia Engineering, 182, 18-24. https://doi.org/10.1016/j.proeng.2017.03.105

Alias, Z., Zawawi, E. M. A., Yusof, K., \& Aris, N. M. (2014). Determining Critical Success Factors of Project Management Practice: A Conceptual Framework. Procedia - Social and Behavioral Sciences, 153, 61-69. https://doi.org/10.1016/j.sbspro.2014.10.041

Arantes, A., Da Silva, P. F., \& Ferreira, L. M. D. F. (2016). Delays in construction projects Causes and impacts. Proceedings of 2015 International Conference on Industrial Engineering and Systems Management, IEEE IESM 2015, (October), 1105-1110. https://doi.org/10.1109/IESM.2015.7380293

Aziz, R. F., \& Abdel-Hakam, A. A. (2016). Exploring delay causes of road construction projects in Egypt. Alexandria Engineering Journal, 55(2), 1515-1539. https://doi.org/10.1016/j.aej.2016.03.006.

Castro Márquez, D.E., Velásquez Pérez, T. \& Castro Silva, H.F. 2018. Integración de seguridad y gestión de servicios en el gobierno de las tecnologías de la 
información. Revista Colombiana de Tecnologías de Avanzada. ISSN: 1692-7257 - Volumen 2 - Número 32.

Castro Silva, H.F., Rodriguez Cañas, G.A. \& Montes Guerra, M. (2020). Conflict Management in International Cooperation Project Teams: Perspective of a Project Manager in Colombia. En H. M.-S.-P.-U. Nelson Antonio Moreno-Monsalve, Handbook of Research on Project Management Strategies and Tools for Organizational Success (págs. 353-375). Hershey, PA: IGI Global. ISBN13: 9781799819349; ISBN10: 1799819345; EISBN13: $\quad 9781799819356$. doi:10.4018/978.

Castro Silva, H.F., Rincon González, . \& Montes Guerra, M. (2020). Sustainability on Project Management: An Analysis of the Construction Industry in Colombia. En H. M.S.-P.-U. Nelson Antonio Moreno-Monsalve, Handbook of Research on Project Management Strategies and Tools for Organizational Success (págs. 281-304). Hershey, PA: IGI Global. ISBN13: 9781799819349; ISBN10: 1799819345; EISBN13: 9781799819356 . doi:10.4018/978.

Catalão, F. P., Cruz, C. O., \& Sarmento, J. M. (2019). The determinants of cost deviations and overruns in transport projects, an endogenous models approach. Transport Policy, 74(March 2018), 224-238. https://doi.org/10.1016/j.tranpol.2018.12.008

Cavalieri, M., Cristaudo, R., \& Guccio, C. (2019). On the magnitude of cost overruns throughout the project life-cycle: An assessment for the Italian transport infrastructure projects. Transport Policy, 79(April), 21-36.

https://doi.org/10.1016/j.tranpol.2019.04.001

Cheng, Y. M. (2014). An exploration into costinfluencing factors on construction projects. International Journal of Project Management, 32(5), 850-860. https://doi.org/10.1016/j.ijproman.2013.10.0 03

Constitución política de Colombia. (1991). Constitución política de Colombia.

Cooke-Davies, T. (2002). The "real" success factors on projects. International Journal of Project Management, 20(3), 185-190. https://doi.org/10.1016/S02637863(01)00067-9

Diez Silva, H., Montes Guerra, M., \& Castro Silva, H.F. (2020). Team Conflict Management in
Project Management in Colombia. En $\mathrm{H}$. M.-S.-P.-U. Nelson Antonio MorenoMonsalve, Handbook of Research on Project Management Strategies and Tools for Organizational Success (págs. 49-72). Hershey, PA: IGI Global. ISBN13: 9781799819349; ISBN10: 1799819345; EISBN13: 9781799819356 . doi:10.4018/978.

DNP. (2019). Plan Nacional de Desarrollo plantea inversiones por \$22,1 billones para Boyacá. Retrieved from https://www.dnp.gov.co/Paginas/PlanNacional-de-Desarrollo-plantea-inversionespor-22-1-billones-para-Boyaca.aspx

Doloi, H., Sawhney, A., Iyer, K. C., \& Rentala, S. (2012). Analysing factors affecting delays in Indian construction projects. International Journal of Project Management, 30(4), 479489.

https://doi.org/10.1016/j.ijproman.2011.10.0 04

Gobernación de Boyaca. (2014). Manual de Procedimientos del Banco Nacional de Programas y Proyectos. 1, 91-105. Retrieved from http://www.boyaca.gov.co/

Gobernación de Boyaca. (2019). Manual de Procedimientos del Banco Nacional de Programas y Proyectos. 0, 91-105. Retrieved from http://www.boyaca.gov.co/

Heravi, G., \& Mohammadian, M. (2019). Investigating cost overruns and delay in urban construction projects in Iran. International Journal of Construction Management, $0(0), 1-11$. https://doi.org/10.1080/15623599.2019.1601 394

Jia, G., Yang, F., Wang, G., Hong, B., \& You, R. (2011). A study of mega project from a perspective of social conflict theory. International Journal of Project Management, 29(7), 817-827. https://doi.org/10.1016/j.ijproman.2011.04.0 04

Kerkhove, L. P., \& Vanhoucke, M. (2017). Optimised scheduling for weather sensitive offshore construction projects. Omega (United Kingdom), 66, 58-78. https://doi.org/10.1016/j.omega.2016.01.011

Khlaifat, D. M., Alyagoub, R. E., Sweis, R. J., \& Sweis, G. J. (2019). Factors leading to construction projects' failure in Jordon. International Journal of Construction Management, 19(1), 65-78. https://doi.org/10.1080/15623599.2017.1382 092 
Landauer, M., \& Komendantova, N. (2018). Participatory environmental governance of infrastructure projects affecting reindeer husbandry in the Arctic. Journal of Environmental Management, 223(January), 385-395.

https://doi.org/10.1016/j.jenvman.2018.06.04 9

Lee, C., Won, J. W., Jang, W., Jung, W., Han, S. H., \& Kwak, Y. H. (2017). Social conflict management framework for project viability: Case studies from Korean megaprojects. International Journal of Project Management, 35(8), 1683-1696. https://doi.org/10.1016/j.ijproman.2017.07.0 11

Ley 1150. (2007). Ley 1150 DE 2007. Retrieved from hhttp://www.secretariasenado.gov.co/senado/ basedoc/ley_1150_2007.html

Li, T. H. Y., Ng, S. T., \& Skitmore, M. (2013). Evaluating stakeholder satisfaction during public participation in major infrastructure and construction projects: A fuzzy approach. Automation in Construction, 29, 123-135. https://doi.org/10.1016/j.autcon.2012.09.007

Liu, Z. zhao, Zhu, Z. wei, Wang, H. jia, \& Huang, J. (2016). Handling social risks in government-driven mega project: An empirical case study from West China. International Journal of Project Management, 34(2), 202-218. https://doi.org/10.1016/j.ijproman.2015.11.0 03

Love, P. E. D., Ahiaga-Dagbui, D. D., \& Irani, Z. (2016). Cost overruns in transportation infrastructure projects: Sowing the seeds for a probabilistic theory of causation.

Transportation Research Part A: Policy and Practice, 92, 184-194. https://doi.org/10.1016/j.tra.2016.08.007

Martínez Ardila A.C., Carrillo Zambrano E. 2017. Arquitectura empresarial para la gestión de información de productos de desarrollo tecnológico e innovación en un grupo de investigación en Colombia. Revista Colombiana de Tecnologías de Avanzada. ISSN: 1692-7257 - Volumen 2 - Número 30.

Mendoza Bejarano, J.L., Escobar Durango, L.M. \& Caicedo Villamizar, S.B. 2019. Actividades de estrategia del servicio de itil v3 como lineamiento para la gestión de servicios médicos bajo modalidad de telesalud. Revista Colombiana de Tecnologías de Avanzada. ISSN: 1692-7257 - Volumen 2 Número 34.
Niazi, G. A., \& Painting, N. (2017). Significant Factors Causing Cost Overruns in the Construction Industry in Afghanistan. Procedia Engineering, 182, 510-517. https://doi.org/10.1016/j.proeng.2017.03.145

Odeh, A. M., \& Battaineh, H. T. (2001). Causes of construction delay: Traditional contracts. International Journal of Project Management, 20(1), 67-73. https://doi.org/10.1016/S02637863(00)00037-5

PMI. (2017). Guia de los Fundamentos para la direccion de Proyectos PMBOK (Sexta ed). Retrieved from www.pmi.org

PMI. (2018). El éxito en tiempos de disrupción. Pulse of the Profession de PMI, 12, 32.

Prasad, K. V., Vasugi, V., Venkatesan, R., \& Bhat, N. (2019). Analysis of causes of delay in Indian construction projects and mitigation measures. Journal of Financial Management of Property and Construction. https://doi.org/10.1108/JFMPC-04-20180020

Rachid, Z., Toufik, B., \& Mohammed, B. (2018). Causes of schedule delays in construction projects in Algeria. International Journal of Construction Management, $O(0), 1-11$. https://doi.org/10.1080/15623599.2018.1435 234

Radujković, M., \& Sjekavica, M. (2017). Project Management Success Factors. Procedia Engineering, 196(June), 607-615. https://doi.org/10.1016/j.proeng.2017.08.048

Rosado Gómez, A.A., Jaimes Fernández, J.C. 2018. Revisión de la incorporación de la arquitectura orientada a servicios en las organizaciones. Revista Colombiana de Tecnologías de Avanzada. ISSN: 1692-7257 Volumen 1 - Número 31.

S, Vyas Gayatri S, K. S. (2013). Performance Indicators for Construction Project 1. (1), 61-66.

Sala del Consejo Estado. (2016). Concepto Sala de Consulta C. E 1365 de 2001 Consejo de Estado - Sala de Consulta y Servicio Civil. Retrieved from https://www.funcionpublica.gov.co/eva/gesto rnormativo/norma_pdf.php?i=79773

Sambasivan, M., \& Soon, Y. W. (2007). Causes and effects of delays in Malaysian construction industry. International Journal of Project Management, 25(5), 517-526. https://doi.org/10.1016/j.ijproman.2006.11.0 07

Sanchez, O. P., Terlizzi, M. A., \& de Moraes, H. R. de O. C. (2017). Cost and time project 
management success factors for information systems development projects. International Journal of Project Management, 35(8), 1608-1626.

https://doi.org/10.1016/j.ijproman.2017.09.0 07

Senouci, A., Ismail, A., \& Eldin, N. (2016). Time Delay and Cost Overrun in Qatari Public Construction Projects. Procedia Engineering, 164(June), 368-375. https://doi.org/10.1016/j.proeng.2016.11.632

Sierra, L. A., Yepes, V., \& Pellicer, E. (2017). Assessing the social sustainability contribution of an infrastructure project under conditions of uncertainty.

Environmental Impact Assessment Review, 67(March), 61-72. https://doi.org/10.1016/j.eiar.2017.08.003

Tafazzoli, M., \& Shrestha, P. P. (2017).

Investigating Causes of Delay in U.S.

Construction Projects. Investigating Causes of Delay in U.S. Construction Projects, 611621. Retrieved from http://www.ascpro.ascweb.org

Vanhoucke, M. (2019). Tolerance limits for project control: An overview of different approaches. Computers and Industrial Engineering, 127(May 2018), 467-479. https://doi.org/10.1016/j.cie.2018.10.035

Velásquez Pérez, T., Pérez Pérez, Y.M. \& Flórez, I.C. 2018. Adopción de prácticas de Gobierno de TI en la oficina de Admisiones, Registro y Control UFPSO. Revista Colombiana de Tecnologías de Avanzada. ISSN: 1692-7257 Volumen 1 - Número 31.

Volden, G. H. (2018). Public project success as seen in a broad perspective.: Lessons from a meta-evaluation of 20 infrastructure projects in Norway. Evaluation and Program Planning, 69(March), 109-117. https://doi.org/10.1016/j.evalprogplan.2018.0 4.008 